\title{
UNA ACLARACIÓN NECESARIA A PROPÓSITO DE UNAS PALABRAS DE ROBERTO GONZÁLEZ ECHEVARRÍA
}

\author{
POR \\ ROBERTO FERNÁNDEZ RETAMAR \\ Casa de las Américas
}

En el número doble 164-165 (julio-diciembre de 1993) de la Revista Iberoamericana acabo de leer sorprendido unas palabras de Roberto González Echevarría que por razones morales no me es posible dejar de refutar. Pues si no suelo discutir cuestiones de gusto ni me molesta ver expuestas con altura ideas que no comparto, en este caso razones morales, como dije, me obligan a poner las cosas en su lugar. Sobre todo porque ignoraba que González Echevarría se hubiera sumado a los calumniadores de oficio y beneficio con quienes tampoco discuto. Aquila non caput muscas. Me gustaría saber que las páginas suyas que comento son una triste excepción en él.

Al hablar de Severo Sarduy (quien, según González Echevarría, y en efecto creo que fue así, "para honra suya no se dejó [...] envenenar ni por el odio ni por el deseo de venganza"), González Echevarría aprovecha la desaparición de aquél para exhumar un inventario de agravios, reales o supuestos, que contradice del todo esas virtudes de Sarduy. Se trata, según González Echevarría, de una "galería de la infamia [que] no puede caer en piadoso olvido en este momento de dolor y amargura" (757). El impiadoso recuerdo de González Echevarría incluye el de las únicas palabras que creo haber publicado sobre el autor de Gestos (lo que hice dentro del ambiente de áspera polémica que rodeó a la revista Mundo Nuevo: ambiente que González Echevarría olvida mencionar): "mariposeo neobarthesiano de Sarduy" (Ibid.). Según González Echevarría, di "un matiz 'homofóbico' al ataque por las sugerencias groseras que" esas "palabras tienen para cualquier cubano" (Ibid.). Como González Echevarría nació en Cuba, el lector y la lectora de sus palabras nacidos en otros países podrían pensar que lo que él escribió es cierto. Y es del todo falso, para un cubano o para cualquiera que no haya olvidado el español. En cuanto a esto último, María Moliner, en su Diccionario de uso del español H-Z, Madrid: Editorial Gredos, 1982, página 353, enumera los siguientes sentidos para la palabra "mariposear": "Ser inconstante en los gustos o aficiones. Particularmente galantear un hombre distintas mujeres". Eso, en cuanto al español en general. Por su parte, Esteban Rodríguez Herrera, en su Léxico mayor de Cuba, vol. II, La Habana: Editorial Lex, 1959, página 239, menciona un solo significado para "mariposear": "Galantear, enamorar a las mujeres por mero pasatiempo y distracción, sin tomar en serio a ninguna, y saltar de una en otra, semejando a la mariposa, que anda de flor en flor". Así pues, ni en cuanto al área total del español (que es la que tengo en consideración cuando escribo, como es lógico), ni en cuanto a la reducida área cubana, hay en el vocablo que empleé "matiz "homofóbico"" alguno, y "las 
sugerencias groseras" que según González Echevarría tienen mis palabras "para cualquier cubano" sólo las tienen (sabe Dios por qué razón) para él. A fin de no ser impiadosos con el profesor González Echevarría, pensemos que olvidó cómo se habla en el país donde naciera. También olvidó otras cosas, por cierto. Así, que en su poema "Musa traviesa", de Ismaelillo (para sólo aducir un ejemplo), entre los vocablos cariñosos que Martí dedica a su hijo está "mariposa". ¿Lo hubiera hecho de implicar el término el "matiz "homofóbico"”, las "sugerencias groseras" que González Echevarría le ha inventado? Otro olvido no es menos singular. Unas líneas después de las anteriores, González Echevarría nos ilustra: “'pájaro' quiere decir homosexual en Cuba, por lo cual toda [sic] alusión a plumas o vuelo es clara" (758). González Echevarría olvidó que en 1983 publicó un libro (que me envió con una exalumna suya, afectuosamente dedicado, confesión que espero que no lo comprometa, aunque siempre le queda el recurso de olvidar el hecho), cuyo título es Isla a su vuelo fugitiva. Ensayos críticos sobre literatura hispanoamericana, Madrid: Ediciones José Porrúa Turanzas S.A. 1983. No me extraña, a partir de esto, que González Echevarría llame "olvidable" a una recordada y valiente antología de Ambrosio Fornet, también caricaturizado por González Echevarría en sus páginas, cuando a un libro de él mismo no sólo lo considera olvidable, sino que lo olvidó. De tomar en serio la hermenéutica nada científica de quien lea esa obra suya queda advertido. Pero nadie que se respete puede tomar en serio tal hermenéutica.

Aunque hay otras inaceptables alusiones a mí en el texto de González Echevarría (casi todas las cuales se vienen abajo como un castillo de naipes, dado que la premisa mayor es falsa), sólo mencionaré una más. Pero antes de pasar a ella, debo decir que la acusación calumniosa que me hiciera González Echevarría me es particularmente inaceptable, porque me cuento con orgullo entre quienes en mi país, durante años, hemos dado contra la homofobia, tan nefasta, y de la que creo que por desgracia ninguno de nuestros países está salvado, una batalla felizmente victoriosa (hasta donde esto puede decirse en casi cualquier parte), como lo muestra el más reciente capítulo de esa batalla: la película Fresa y chocolate. Me alegra recordar que su director, Tomás Gutiérrez Alea, me editó hace cuarenticuatro años, en una imprentica que tenía en su casa cuando ambos éramos estudiantes, mi primer cuaderno, Elegía como un himno, un poemario dedicado a la memoria del gran poeta y luchador social Rubén Martínez Villena. Desde antes de 1950 hasta hoy me he sentido y me siento muy identificado con Gutiérrez Alea.

Y aquí viene aludir al último punto del texto de González Echevarría que mencionaré. Según él, "en 1991, cuando la desbandada de escritores cubanos se hizo más aguda", yo le envié

una carta a Sarduy invitándolo a un "conversatorio" sobre su obra en la Casa de las Américas, y pidiéndole una colaboración para la revista [en nota al pie, González Echevarría dice que Severo Sarduy le hizo llegar copia xérox de esa carta]. El establishment cultural cubano, antes poderoso y agresivo, pero ahora boqueando, le hacía un guiño grotesco al antiguo paria [sic] que se había hecho "un escritor de fama mundial", según dice en la citada carta su vocero (758-759).

En esta ocasión no es posible favorecer a González Echevarría con el beneficio de la duda, y conjeturar que olvidó. Aquí, crudamente, hay que aceptar que procedió a ocultar 
y a mentir. Si tiene la carta, ¿por qué no la publicó? La alude como "citada", pero lo que en realidad ha hecho no es citarla, sino dar una versión (nuevamente falsa) de ella. La carta, que en efecto existe y llevó a París mi entrañable Lilia Carpentier, nació de una conversación en que ella me habló de que Sarduy estaba enfermo, al parecer de muerte. Ante ese hecho, le escribí la carta que en circunstancias similares volvería a escribirle sin cambiar una coma. En absoluto pesó en su escritura, ni en nada que hago, "la desbandada" que, equivocado otra vez, menciona González Echevarría (¿será una alusión homofóbica suya?). Desde 1959 he presenciado muchas desbandadas: primero, de esbirros batistianos y otros cómplices del atroz régimen depuesto entonces; luego, de afectados por las justicieras leyes revolucionarias, y más tarde, por muchas razones (incluyendo entre ellas, naturalmente, el rechazo a la revolución), de las más diversas personas, no pocas de las cuales me hubiera gustado que permanecieran en Cuba. Hace tiempo que el cruel, ilegal e inmoral bloqueo que padecemos, y ha sido recrudecido (lo que también olvida mencionar González Echevarría), hace engrosar la emigración cubana con quienes, habida cuenta de la gran dureza de nuestra vida material, salen en busca de alivio a esa dureza. Ello es frecuente en los países pobres como el mío: mucha gente del Sur, en el mundo entero, se está trasladando (o quiere hacerlo) al Norte. Sé que la emigración cubana, como cualquier otra, es muy compleja, y no emitiré un juicio superficial sobre ella, donde por añadidura tengo tantas amistades. Pero ninguna desbandada me hará cambiar. Soy lo que soy desde que, muchacho aún, grandes espíritus como Martí, Antonio Machado, Shaw, Martínez Villena, mis compañeros de Orígenes, decidieron para siempre el sesgo de mi alma. Ello me llevó a que, no obstante el amor que siento por la cultura estadounidense, y el honor que me significó ser a mis veintisiete años profesor en la Universidad de Yale (invitado por el grande y generoso maestro José Juan Arrom), declinara el honor también grande que me hiciese la Universidad de Columbia, Nueva York, al invitarme a enseñar allí a partir de abril de 1959. Decliné, para permanecer en mi patria, ante la que se abrían posibilidades de independencia, eticidad y reconstrucción cuyos riesgos conocía muy bien. ¿Cómo voy a modificar mi conducta ahora, cuando mi patria afronta en grado altísimo esos riesgos, y cuando vive uno de sus más difíciles momentos? Puedo repetir con el personaje de Valéry que la estupidez no es mi fuerte. Aunque sobre todo me gusta repetir la sentencia de don Pedro Albizu Campos según la cual el primer valor de un ser humano es el valor. Pero ya he hablado demasiado de mí. Transcribo de inmediato la carta que envié a Sarduy cuando lo supe herido de muerte. Juzgue quien tiene ahora la oportunidad de leerla, oportunidad de que lo privó González Echevarría:

La Habana, 31 de mayo de 1991

Severo Sarduy

París

Amigo Severo (pero no severo amigo: broma tonta que te habrán hecho mil veces):

No sé si te he escrito antes, no sé si nos hemos escrito. Recuerdo que nos conocimos creo que en el año 1958, en casa de Cintio y Fina, a quienes tú habías ido a visitar con Rolando Escardó. 
Muchas cosas han pasado desde entonces, y entre ellas el hecho grato de que te has convertido en un escritor de fama mundial. Pero, como supondrás, no es por eso que te mando estas líneas con nuestra amiga Lilia Carpentier. Tampoco para agradecerte el libro tuyo Ensayos generales sobre el barroco, que me dio Elizabeth Burgos, y que supuse con alegría que me habías mandado tú, aunque venía sin dedicatoria.

Te escribo, Severo, para agradecerte tus reiteradas alusiones carinosas a nuestra Cuba (nuestra: tuya y mía), ahora que tanta gente encuentra de buen gusto desvincularse de nuestra isla, acosada como una cierva herida (la imagen es de Martí, sobre él mismo), o incluso llegar a escribir, lo que vi con estupor, que Cuba no existe.

La más reciente de esas menciones tuyas la leí en un cable de la agencia EFE fechado en Roma el 23 de este mes. Pero ya habíamos leído muchas otras, razón por la cual en el próximo número de la revista Casa de las Américas, cuya dirección he reasumido, hay unas líneas cariñosas para ti: confio en que te gusten. Además, en septiembre habrá en la Biblioteca de esta Casa un "café-conversatorio" (cubanismo o barbarismo, no lo sé bien) sobre tu obra, de la cual hablarán los escritores Eduardo Heras León, Rogelio Rodríguez Coronel y Jorge Luis Arcos.

Wilde escribió (y a Borges le gustaba citar esas palabras) que arrepentirse de un acto es modificar el pasado. A mí también me gustan esas palabras, pero, para bien o para mal, creo que tiene más razón el viejo verso de Musset: "Au passé, pour quoi rien changer?" Por eso no me vuelvo al desvanecido pasado, sino al porvenir, que es lo que me queda, y que a estas alturas para mí no es mucho: dentro de unos días voy a cumplir sesentiún años (lo que me da verguenza, al pensar en tantos de mis hermanos muertos con muchos menos años: Novalis, Keats, Lautréamont, Rimbaud, Casal, Federico ...). Y me haría feliz que en ese ya escaso porvenir nos encontráramos otra vez, otras veces, como aquella tarde lejanísima pero recordada en el jardín de Cintio y Fina.

Quizás debía haber comenzado esta deshilvanada carta agradeciéndote lo mucho y bello que has hecho por Lezama, a quien sabes cuánto le debo. ¿Cómo podría olvidar que a mis veinte años acogió unos pobres versos míos en su deslumbrante Orígenes, y selló mi vida para siempre?

¿Me mandarías algo inédito tuyo para publicar en la revista Casa? ¿Me lo traerías personalmente, en lo que no puede ser sino un lindo retorno al país natal, donde tanto se te admira, y donde se alegrará de abrazarte tu viejo amigo

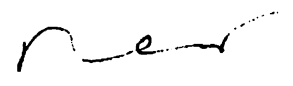

Roberto Fernández Retamar 